\title{
APLIKASI NEWS READER BERITA LOKAL BERBASIS ANDROID
}

\author{
Bambang Yuwono, Heriyanto, Tantra Nurhuda \\ Jurusan Teknik Informatika UPN "Veteran" Yogyakarta \\ Jl. Babarsari 2 Tambakbayan 55281 Telp (0274) 485323 \\ e-mail : bambangy@gmail.com, mr_heriyanto_skom@yahoo.com, kentruk2007@gmail.com
}

\begin{abstract}
News reader is a software or web service that serves to display a summary of the latest posts. RSS is typically used on websites that update content dynamically. RSS is an open method for collecting and pooling the content of the pages of a website. The method used in the making of this application is the grapple. The programming language used is Java and php. While building a database using mySQL. This application is useful to facilitate mobile phone users to know the latest news. In this application there are news categories that can be selected by the user, namely the category of politics, economics, sports, technology, education and entertainment. Featured news picked up from a local news portal website rss Indonesia. Users can view the details of the news and share news via facebook and twitter. There was also the news search feature that utilizes existing news search feature on the website news provider.
\end{abstract}

\section{Keywords : Application, News Reader, RSS}

News reader adalah sebuah perangkat lunak atau layanan website yang berfungsi untuk menampilkan ringkasan tulisan terbaru. RSS biasanya digunakan pada website yang memperbaharui isinya secara dinamis. RSS adalah sebuah metode terbuka untuk pengumpulan dan penyatuan isi halaman sebuah website. Metode yang digunakan dalam pembuatan aplikasi ini adalah GRAPPLE. Bahasa pemrograman yang digunakan adalah java dan php. Sedangkan pembuatan basis data menggunakan mySQL. Aplikasi ini berguna untuk mempermudah pengguna telepon seluler mengetahui berita terkini. Di dalam aplikasi ini terdapat kategori-kategori berita yang bisa dipilih oleh pengguna yaitu kategori politik, ekonomi, olahraga, teknologi, pendidikan dan hiburan. Berita yang ditampilkan mengambil dari rss website portal berita lokal Indonesia. Pengguna bisa melihat detail berita dan membagikan berita melalui situs jejaring sosial facebook dan twitter. Selain itu ada juga fitur pencarian berita yang memanfaatkan fitur pencarian berita yang ada di dalam website penyedia berita.

Kata kunci : Aplikasi, News Reader, RSS

\section{PENDAHULUAN}

Berita adalah laporan tentang suatu kejadian yang sedang terjadi. Kejadian tersebut dilaporkan oleh wartawan dan kemudian laporan tersebut menjadi fakta atau ide terkini. Laporan atau yang biasa disebut berita tersebut kemudian diseleksi oleh redaksi, apakah layak tampil atau tidak. Berita bisa disajikan dalam bentuk media cetak, siaran di televisi dan melalui internet.

Di era global seperti saat ini, internet sudah merambah berbagai bidang misalnya sosial, periklanan, dan bisnis. Sejalan dengan kemajuan internet tersebut, banyak berita yang disajikan melalui internet. Beberapa website penyedia berita menambahkan fasilitas RSS (really simple syndication). RSS digunakan untuk menyebarkan ringkasan tulisan terbaru. Untuk menampilkan berita dari website yang mempunyai fasilitas RSS dibutuhkan sebuah aplikasi yang disebut news reader. News reader adalah sebuah perangkat lunak atau layanan website yang berfungsi untuk menampilkan ringkasan tulisan terbaru seperti tajuk berita, blog, podcast, dan video blog pada suatu lokasi agar mudah dibaca.

Perangkat seluler saat ini semakin canggih. Hal ini memungkinkan pengguna untuk mengakses berita dari internet hanya dengan menggunakan sebuah telepon seluler. Salah satu sistem operasi telepon seluler yang canggih yang sedang berkembang pesat saat ini 
adalah android. Android adalah sebuah sistem operasi yang bersifat open source. Artinya programmer diizinkan oleh pengembang sistem operasi untuk membuat, mengubah, mengembangkan dan menyebarluaskan aplikasi. Dengan memanfaatkan teknologi telepon seluler yang menggunakan sistem operasi android, sangat memungkinkan dibuat sebuah aplikasi news reader yang berfungsi untuk menampilkan berita dari website yang mempunyai fasilitas RSS.

\section{TINJAUAN PUSTAKA}

Penelitian tentang news reader sudah pernah dilakukan oleh Wibisono Margono dengan membuat penelitian pembuatan situs pembaca sindikasi data dengan standar RSS menggunakan PHP. Terdapat perbedaan antara aplikasi yang dibangun dengan aplikasi sebelumnya, perbedaannya antara lain sebagai berikut :

1. Aplikasi sebelumnya menggunakan metodologi waterfall, sedangkan aplikasi yang akan dibangun menggunakan metodologi GRAPPLE.

2. Aplikasi sebelumnya menggunakan bahasa pemograman php, sedangkan aplikasi yang akan dibangun ini menggunakan bahasa pemograman java.

3. Aplikasi yang sebelumnya berbasis Web, sedangkan aplikasi yang akan dibangun ini berbasis sistem operasi ponsel Android.

\section{ANALISIS DAN PERANCANGAN}

Pada analisis dan perancangan ini akan dibahas tiga segmen dalam metodologi Guidelines for Rapid APPlication Engineering (GRAPPLE) yaitu segmen pengumpulan kebutuhan (requirement gathering), analisis (analysis) dan perancangan (design). Dalam segmen analisis akan digunakan tiga diagram UML yaitu diagram use case, diagram class dan diagram sequence. Sedangkan dalam segmen perancangan digunakan diagram activity serta rancangan prototype antarmuka.

\section{Pengumpulan Kebutuhan (Requirements gathering)}

Ada tiga aksi yang akan dibahas dalam segmen ini yaitu pengumpulan informasi, analisis domain, dan analisis kebutuhan sistem. Segmen ini berguna untuk memperjelaskan pemahaman terhadap masalah.

a. Analisis Domain

Analisis domain berguna untuk memperoleh gambaran atau pengertian yang bersifat menyeluruh. Analisis domain ini sendiri pada dasarnya dapat berubah jika sistem yang dibangun dalam aplikasi turut berubah. Penyesuaian ini ditujukan untuk meningkatkan kesesuaian alur sistem dengan objek dan komponen yang membangun sistem.

Android merupakan salah satu sistem operasi pada smartphone yang sistem kerjanya berjalan diatas kernel linux. dan merupakan platform terbuka bagi para pengembang untuk menciptakan aplikasi. Sistem operasi android tidak hanya dimiliki oleh satu vendor saja. Google mempersilakan vendor mana saja untuk menggunakan sistem operasi android.

Aplikasi News Reader Berita Lokal Berbasis Android ini akan dibangun menggunakan prinsip client server dimana client (menggunakan teknologi Android) dan server mySQL untuk menyimpan sumber berita yang akan diakses oleh aplikasi.

Aplikasi bagi client berfungsi sebagai alat untuk mengetahui dan membaca berita terbaru. Dalam aplikasi ini client dapat menggunakan aplikasi ini untuk mengetahui berita terbaru dari RSS beberapa situs berita yang sudah disediakan oleh pengembang. Berita yang disediakan dibagi ke dalam beberapa kategori untuk mempermudah client memilih berita sesuai keinginan. Selain itu client juga dapat membagikan berita melalui situs jejaring sosial facebook dan twitter. Fasilitas lain dari aplikasi ini adalah adanya fitur pencari berita melalui fungsi search yang ada di dalam website berita

b. Identifikasi Sistem

Identifikasi sistem merupakan gambaran model diagram untuk menunjukkan tata letak sebuah sistem secara fisik dengan menampilkan bagian-bagian perangkat lunak yang berjalan pada perangkat keras (hardware). Pada aplikasi ini perangkat keras yang digunakan adalah ponsel smartphone yang menggunakan sistem operasi Android untuk menjalankan aplikasi newsreader lokal berbasis android. Aplikasi akan dibangun menggunakan Integrated 
Development Environment (IDE) Eclipse versi indigo. Pertukaran data menggunakan JSON (JavaScript Object Notation) dan parsing XML. Aplikasi ini melibatkan user dan admin. Data berita diperoleh dari website berita sedangkan data sumber berita diperoleh dari database pengembang aplikasi. Adapun diagram identifikasi sistem dapat dilihat pada gambar 1.

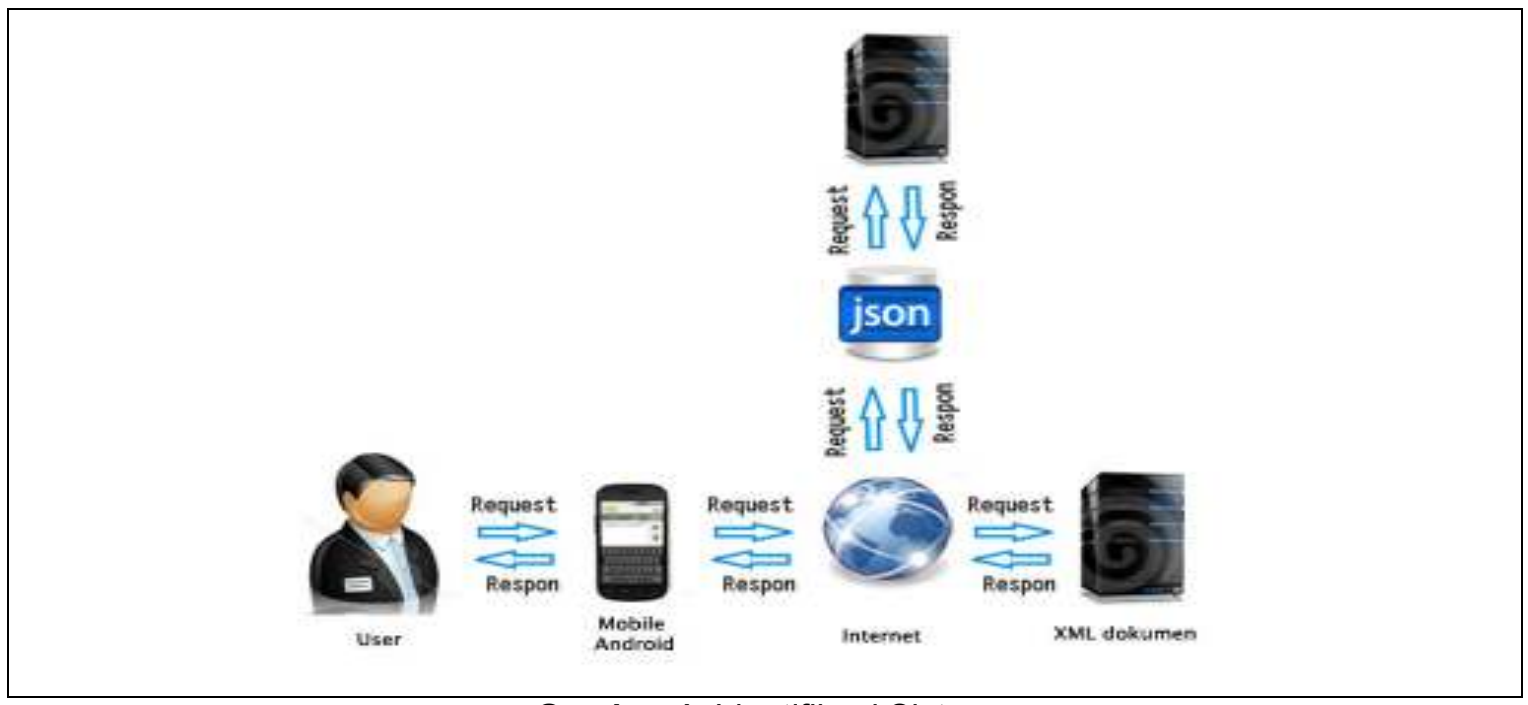

\section{Analisis}

\section{Gambar 1. Identifikasi Sistem}

Analisis merupakan proses untuk menganalisa dari proses pengumpulan kebutuhan atau Requirement Gathering dimana hasil analisa tersebut diwujudkan dalam bentuk permodelan menggunakan diagram UML. Ada dua point penting dalam tahap analisis, yaitu identifikasi kebutuhan sistem dan memperinci diagram kelas (Schmuller, 1999). Analisis dalam penelitian ini membahas tentang analisis perancangan sistem yang akan dibangun menggunakan UML sebagai bahasa spesifkasi standar untuk mendokumentasi, menspesifikasi, dan membangun sebuah sistem dengan menggunakan beberapa diagram. Ada tiga macam diagram UML yang akan dibahas yaitu diagram use case, diagram class, dan diagram activity.

a. Diagram Usecase

Diagram use case untuk client di dalam sistem yang akan dibangun terdapat satu aktor yaitu user. User mempunyai hak untuk memilih kategori berita, membaca cuplikan berita, membaca berita selengkapnya, membagikan berita ke jejaring sosial, melakukan pencarian berita dan meihat about aplikasi. Diagram Use case untuk client dapat dilihat pada gambar 2

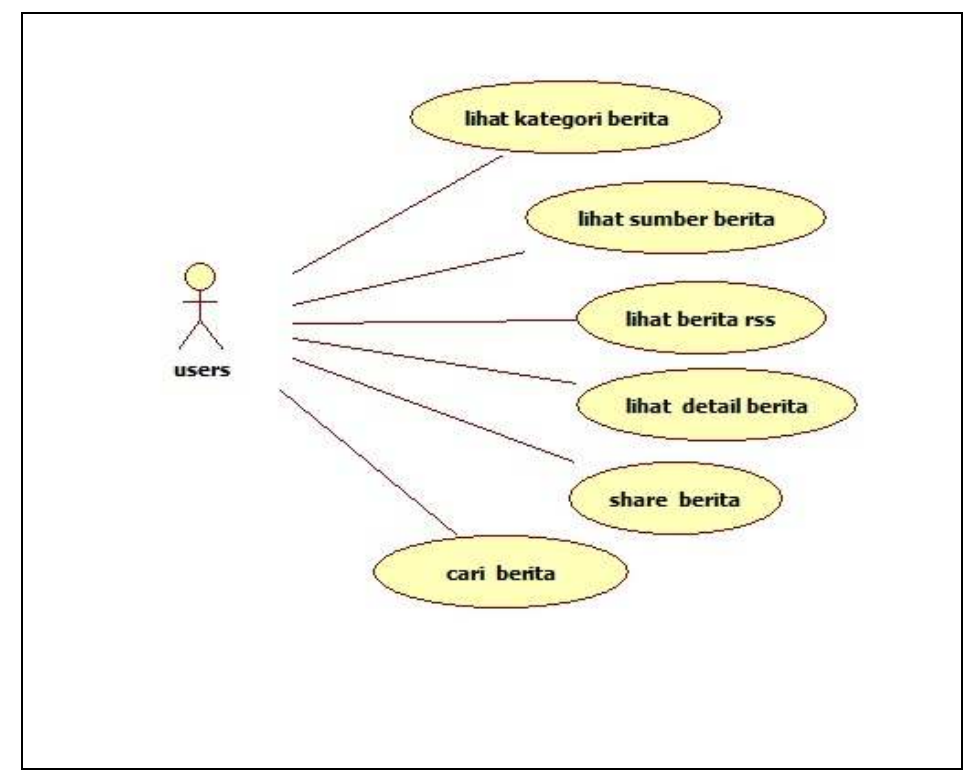

Gambar 2. Diagram use case client 
Di dalam diagram use case untuk server admin memiliki hak untuk mengolah sumber berita serta login dan logout. Pengolahan data yang dilakukan admin adalah proses pengeditan, penambahan serta penghapusan data. Diagram use case untuk server dapat dilihat pada gambar 3.

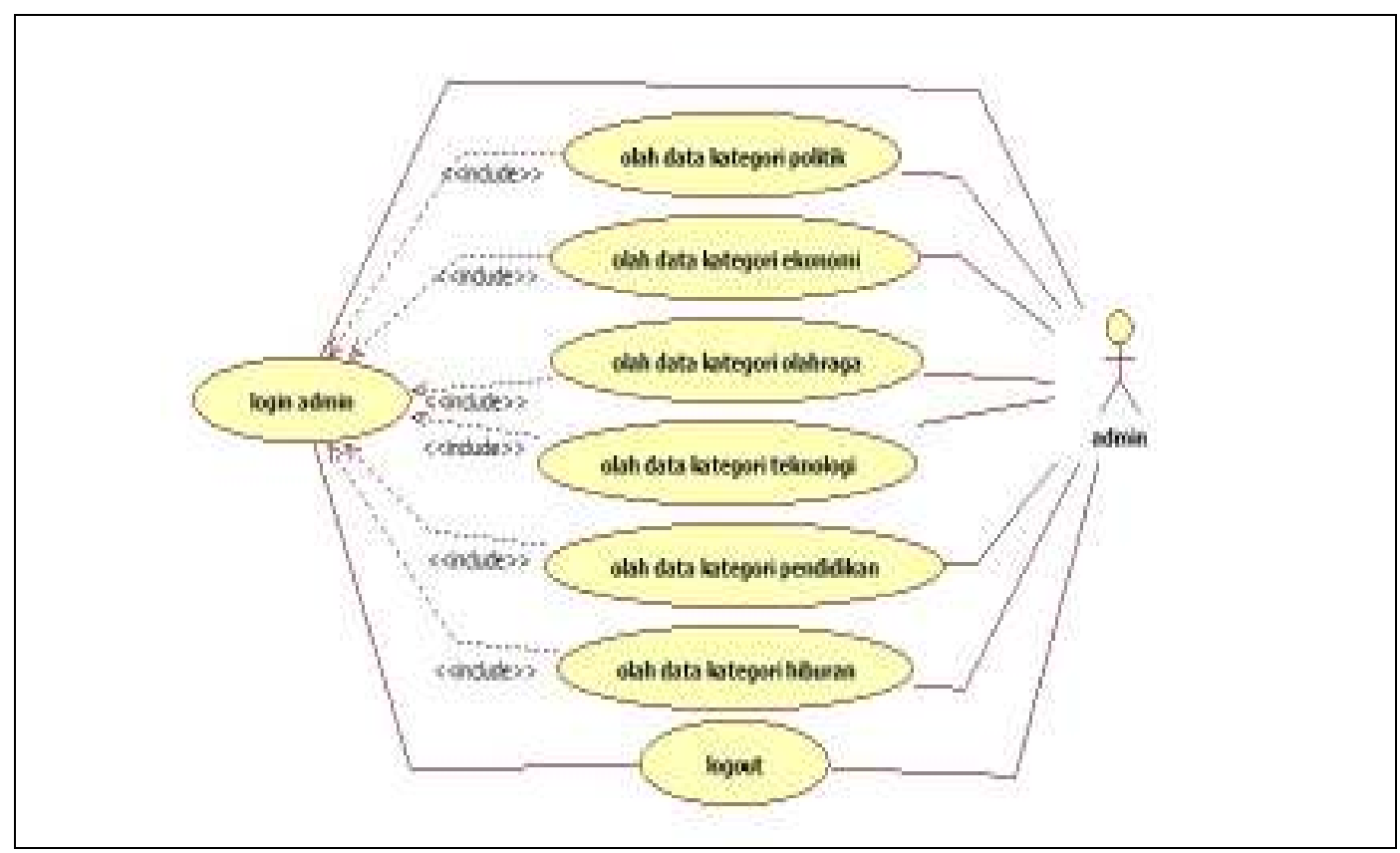

Gambar 3. Diagram use case server

b. Diagram Sequence Kategori

Di dalam diagram sequence kategori terdapat satu aktor dan dua life line. User memiliki hak akses untuk melihat kategori berita yang ada didalam aplikasi. User masuk ke aplikasi, selanjutnya life line DashboardActivity akan menampilkan kategori berita yang ada di dalam aplikasi newsreader lokal berbasis android. Gambar diagram sequence kategori dapat dilihat pada gambar 4 .

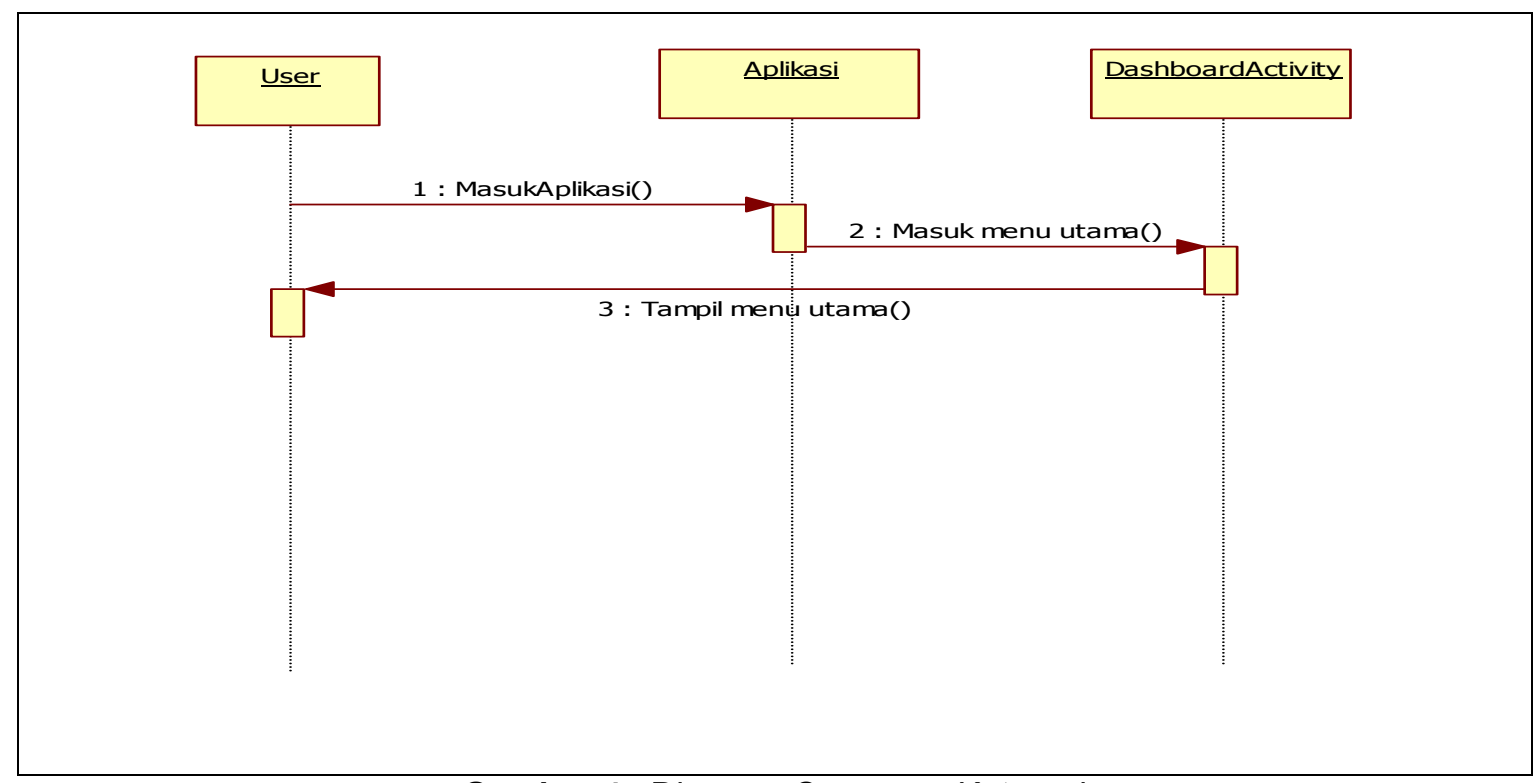

Gambar 4. Diagram Sequence Kategori 
c. Diagram Sequence List Sumber Berita

Diagram sequence List sumber berita terdapat satu aktor dan tiga life line, dimana user memiliki hak akses untuk memilih sumber berita yang terdapat di dalam aplikasi. Setelah user memilih kategori selanjutnya life line ListBerita akan melakukan request sumber berita yang telah disimpan di database server dan setelah berhasil maka data berita akan ditampilkan dalam bentuk listview. Gambar diagram sequence sumber berita dapat dilihat pada gambar 5 .

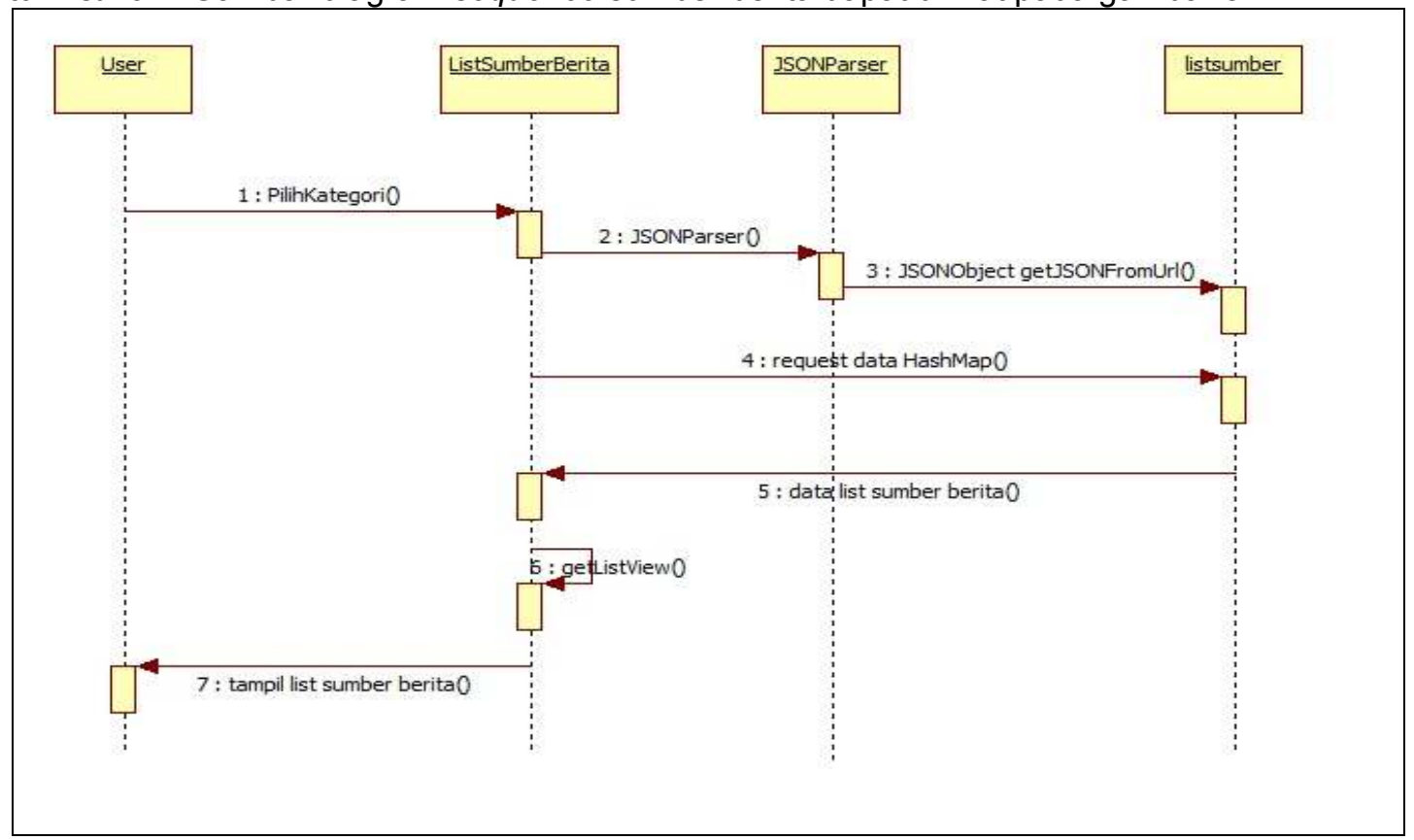

Gambar 5. Diagram Sequence List Sumber Berita

d. Diagram Sequence Lihat Berita

Diagram sequence lihat berita terdapat satu aktor dan empat life line, dimana aktor memiliki hak akses melihat berita yang diambil dari rss. Gambar diagram sequence dapat dilihat pada gambar 6 .

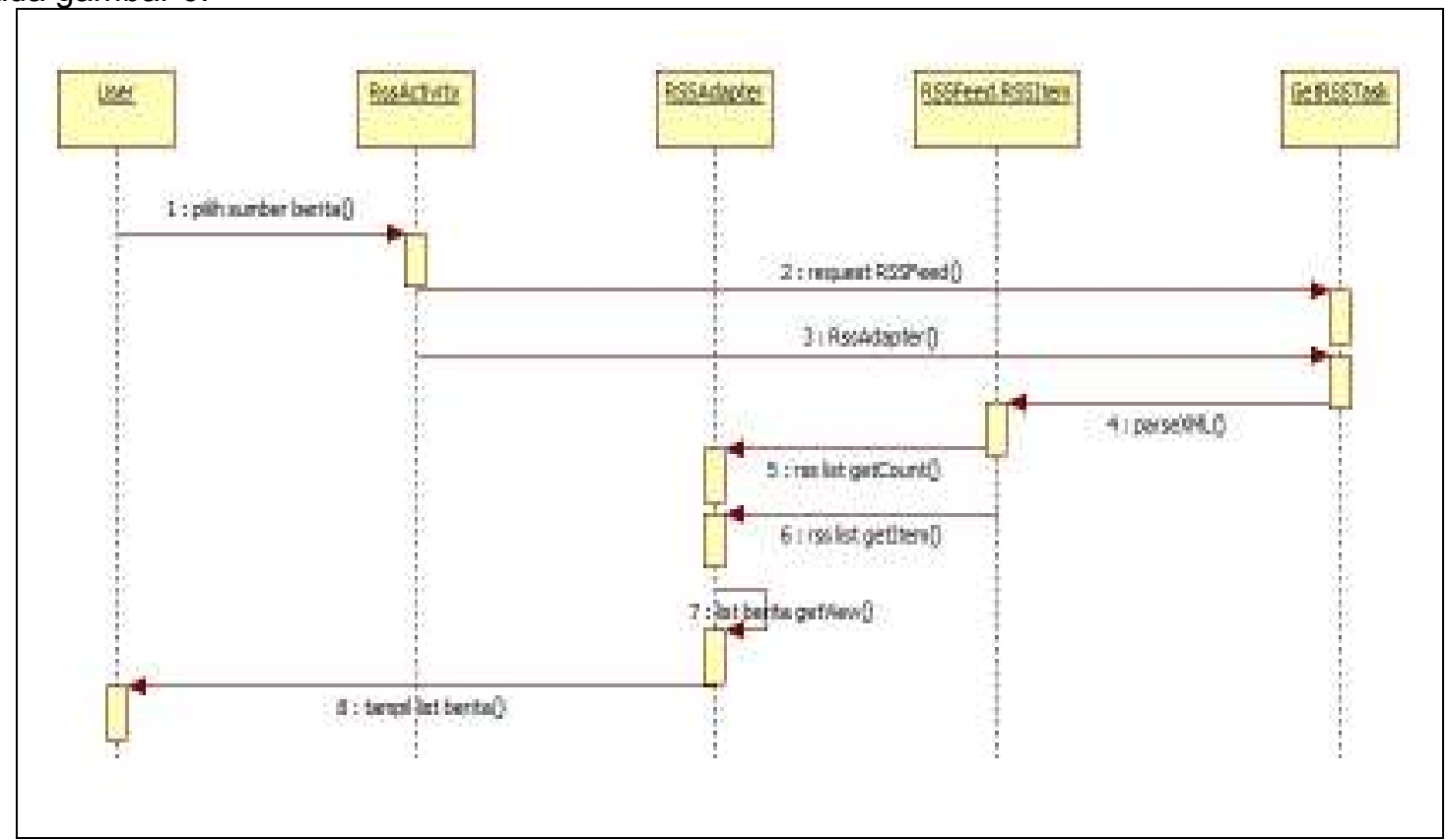

Gambar 6. Diagram Sequence Lihat Berita 
e. Diagram Class

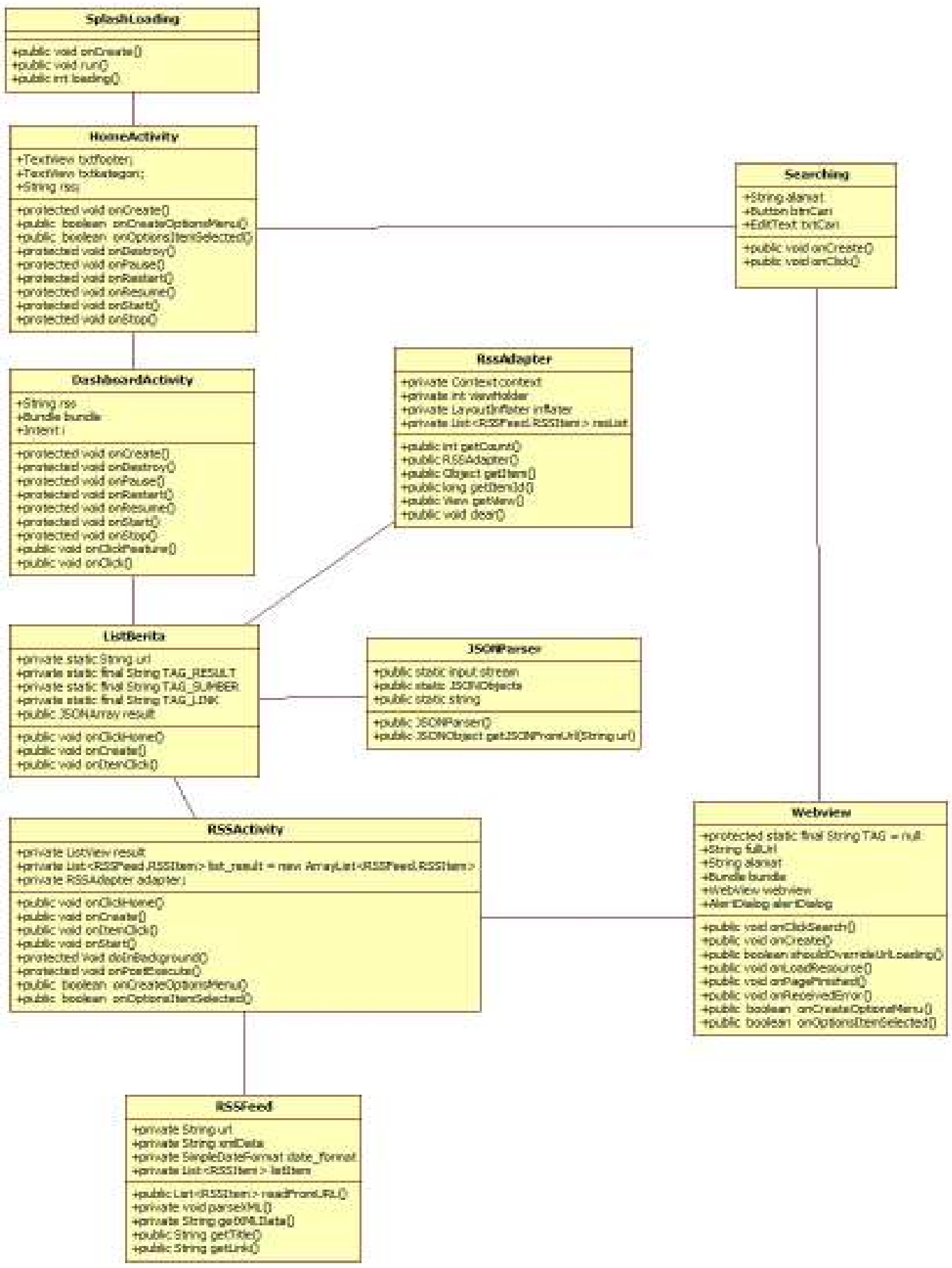

Gambar 7. Diagram Class 
3. Design

Pembuatan design aplikasi dibagi dalam tiga bagian yaitu diagram activity, struktur menu, dan perancangan antar muka.

\section{Diagram Activity}

Diagram activity menggambarkan berbagai alur aktivitas dalam sistem yang sedang dirancang. Diagram activity juga dapat menggambarkan proses paralel yang mungkin terjadi pada beberapa eksekusi.

a. Diagram Activity Kategori Berita

Diagram activity kategori berita memiliki dua aksi yaitu user dan aplikasi. Dalam sistem ini secara otomatis akan menampilkan kategori berita saat user masuk ke dalam aplikasi newsreader local berbasis android. Diagram activity kategori berita dapat dilihat pada gambar 8.

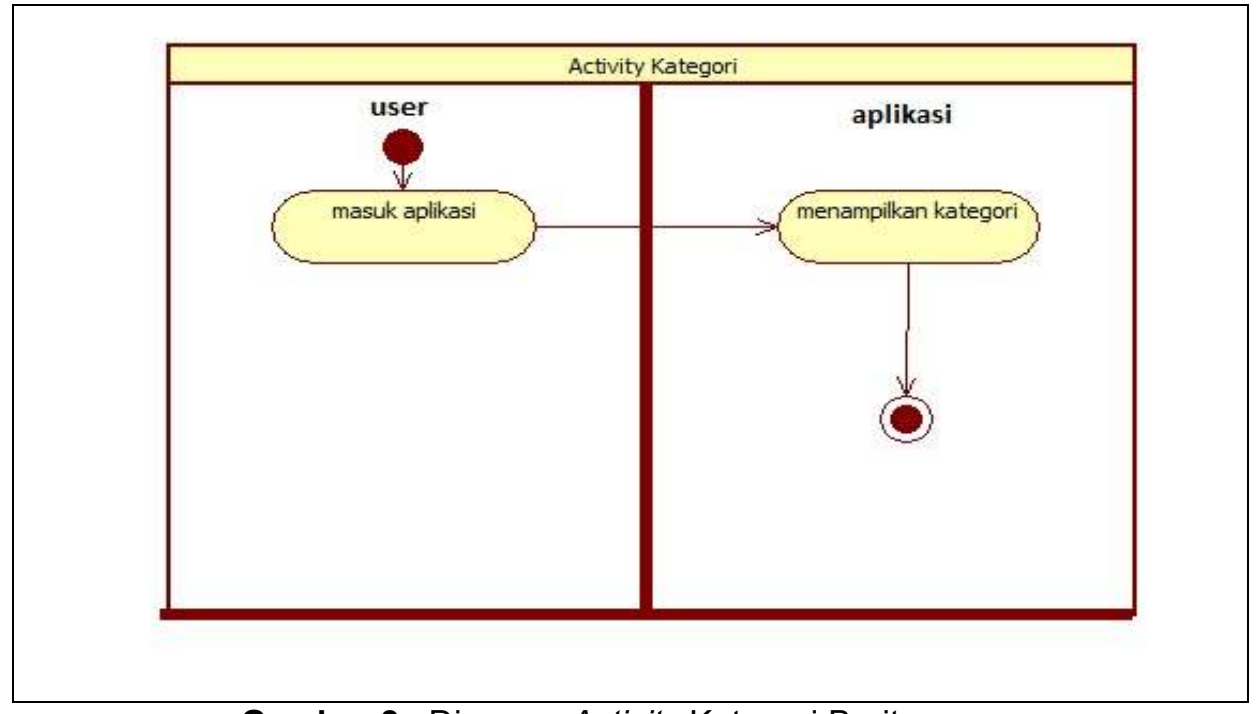

Gambar 8. Diagram Activity Kategori Berita

b. Diagram Activity List Sumber Berita

Diagram activity list sumber berita memiliki dua aksi yaitu user dan aplikasi. Dalam sistem ini akan menampilkan sumber berita saat user memilih salah satu kategori yang ada di dalam aplikasi. Diagram activity sumber berita dapat dilihat pada gambar 9 .

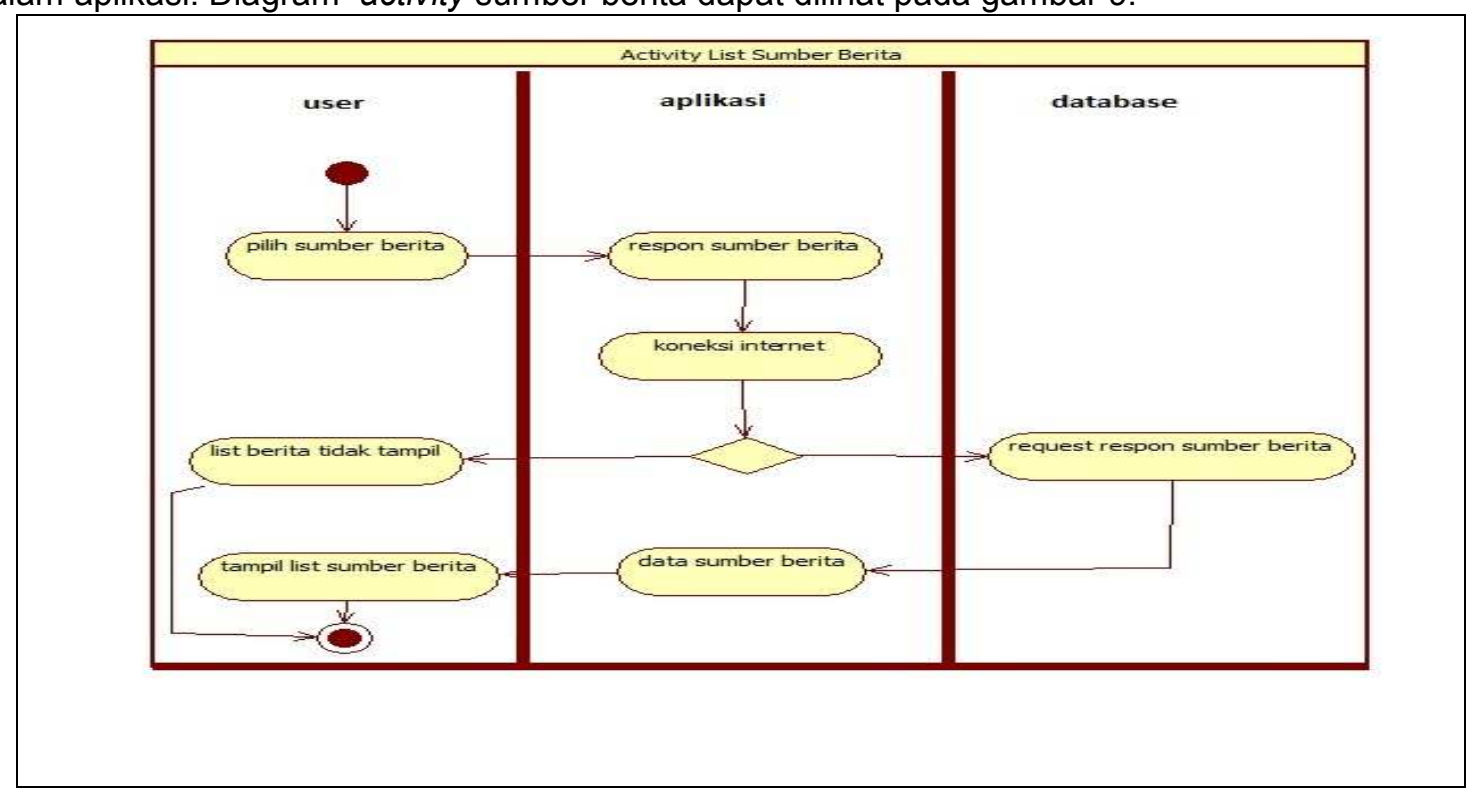

Gambar 9. Diagram Activity List Sumber Berita 
c. Diagram Activity Lihat Berita

Diagram activity lihat berita memiliki dua aksi yaitu user dan aplikasi. Dalam sistem ini akan menampilkan berita saat user memilih salah satu sumber berita yang ada di dalam aplikasi. Diagram activity sumber berita dapat dilihat pada gambar 10.

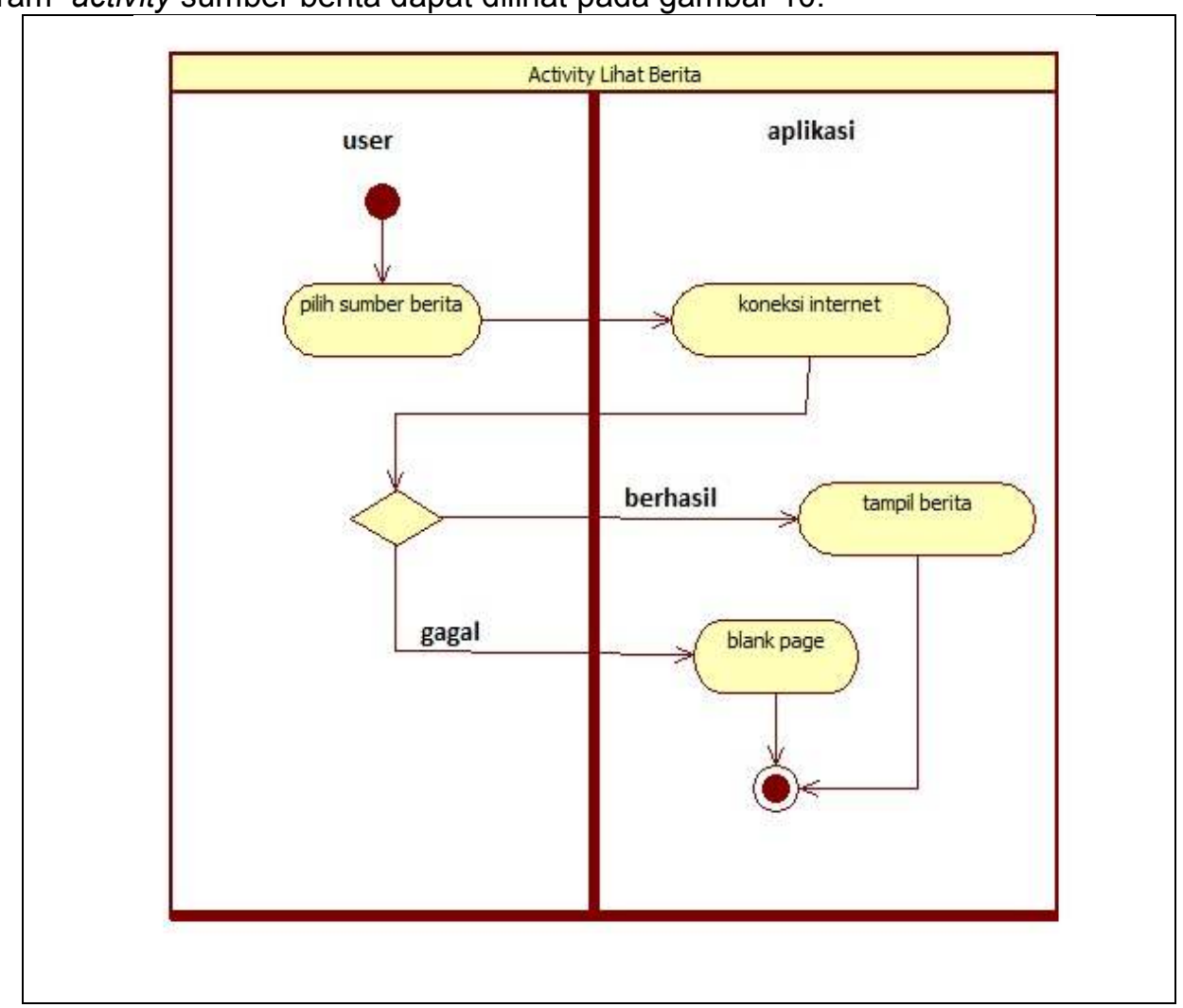

Gambar 10. Diagram Activity Lihat Berita

\section{HASIL PEMBAHASAN}

Halaman kategori berita adalah halaman utama aplikasi. Halaman ini berisi daftar ketegori berita dalam bentuk image button. Pada bagian bawah ada tiga menu yaitu about, search dan exit. Tampilan halamannya dapat dilihat pada gambar 11.

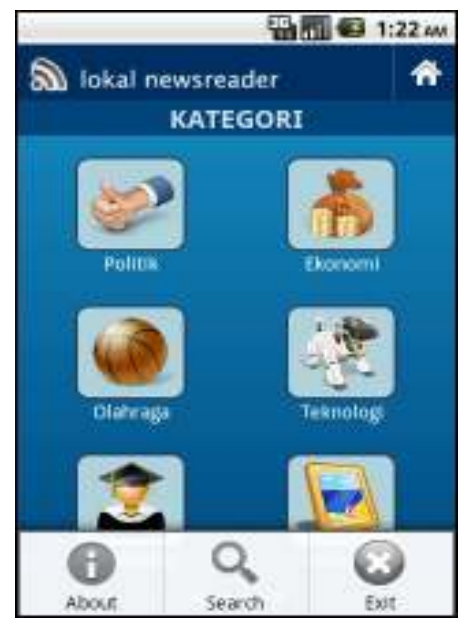

Gambar 11. Halaman Kategori Berita

Halaman List Sumber Berita adalah halaman yang muncul setelah user memilih salah satu kategori berita. Halaman ini berisi tampilan daftar sumber berita dalam bentuk listview. Tampilan halamannya dapat dilihat pada gambar 12 . 


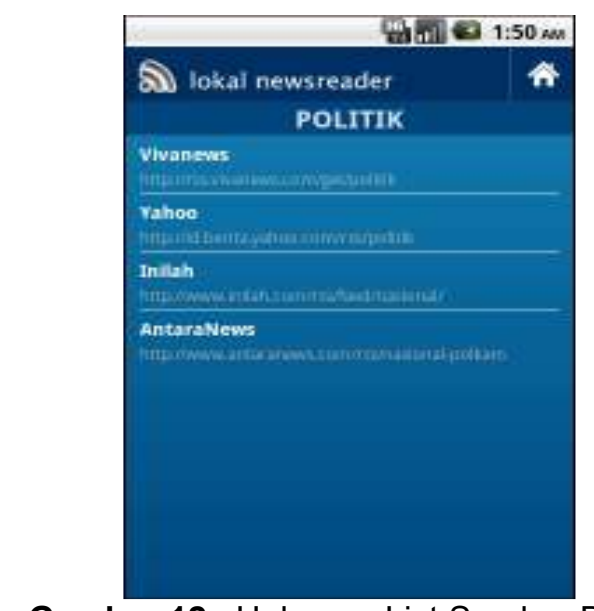

Gambar 12. Halaman List Sumber Berita

Halaman Berita adalah halaman yang muncul setelah user memilih fitur menu berita. Halaman ini berisi tampilan sebuah list konten berita dan nantinya user dapat memilih berita yang terdapat di list konten berita. Tampilan halamannya dapat dilihat pada gambar 13 .

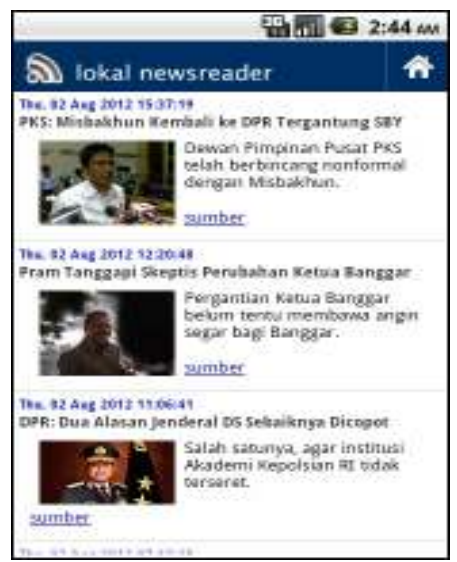

Gambar 13 Halaman Lihat Berita

\section{KESIMPULAN}

Dari analisis perancangan dan implementasi yang telah dilakukan, telah berhasil dibuat Aplikasi News Reader Berita Lokal berbasis Android. Aplikasi ini berfungsi sebagai media yang memberikan kemudahan bagi pengguna dalam mendapatkan berita dari internet. Di dalam aplikasi ini terdapat kategori-kategori berita yang bisa dipilih yaitu kategori politik, ekonomi, olahraga, teknologi, pendidikan dan hiburan. Pengguna bisa melihat detail berita dan membagikan berita melalui situs jejaring sosial facebook dan twitter. Selain itu ada juga fitur pencarian berita yang memanfaatkan fitur pencarian berita yang ada didalam website penyedia berita. Aplikasi ini aman dari segi konten berita karena isi berita yang diambil adalah dari website berita yang sudah terpercaya sehingga bisa digunakan oleh semua usia. 
DAFTAR PUSTAKA

artikel non-personal, 23 Desember 2011, News_reader, Wikipedia Bahasa Indonesia, http://id.wikipedia.org/wiki/News_reader, diakses 13 Februari 2012.

Kadir, Abdul, 2002, Pengenalan Sistem Informasi, Andi, Yogyakarta.

Maolana, Edwin, 25 November 2008, Pengantar RSS, Ilmu Komputer, http://ilmukomputer.org/2008/11/25/pengantar-rss, diakses 13 Februari 2012.

Mulyadi, ST, 2010, Membuat Aplikasi Untuk Android, Multimedia Center Publishing, Yogyakarta.

Schmuller, Joseph, 1999, Sams Teach Yourself UML in 24 Hours, Sams Publishing, Indiana USA.

Suhendar, A, Hariman Gunadi, 2002, Visual Modeling Menggunakan UML dan Rational Rose, Informatika, Bandung.

Wahyudi, J.B. 1991, Komunikasi Jurnalistik; Pengetahuan Praktis Bidang Kewartawanan, Surat Kabar, Majalah, Radio dan Televisi, Alumni, Bandung.

Yuhefizar, Ha Mooduto, dan Rahamat Hidayat, 2009, Cara Mudah Membangun Website Interaktif Menggunakan Joomla (CMS), Elex Media Komputindo, Jakarta. 